\title{
Relevansi Pemikiran Pendidikan KH. Imam Zarkasyi Dalam Pembentukan Intrapersonal Intelegensi
}

\author{
Robiatul Adawiyah; \\ UIN Sunan Ampel Surabaya; \\ Surabaya, Indonesia \\ robiatul.adawiyah19@yahoo.com \\ Ryan Eka Rahmawati; \\ UIN Sunan Ampel Surabaya; \\ Surabaya, Indonesia \\ ryaneka029@gmail.com \\ Mohamad Salik; \\ UIN Sunan Ampel Surabaya \\ Surabaya, Indonesia \\ salik_mohamad@yahoo.com
}

\begin{abstract}
This article discusses about the relevance of KH Imam Zarkasi thoughts of education in developing intrapersonal intelligence. It is a kind of library research using descriptivequalitative method. The resutt of this research shows that KH. Imam Zarkasi s thoughts are still very relevant to be implemented in developing students' intrapersonal intelligence. Among of his thoughts are; 1) developing intrapersonal intelligence can be through two ways; intentionally, that is through education in formal institutions, and unintentionally that is through interaction with the surrounding community and the nature. 2) The method of learning to develop intrapersonal intelligence is through individual training; by entrusting children to carry out their own duties with full responsibility, giving children the opportunity to make their own decisions and be responsible for their decisions, and other similar activities. These thoughts have been applied by KH Imam Zarkasi through the institution he developed, namely Pondok Pesantren Gontor. Among of his renewal efforts are; The implementation learning using classical system, the use of learning methods that provide opportunities for children to develop their thinking power critically, independently and responsibly, and provide extracurricular activities as a forum for students to develop themselves.
\end{abstract}

Artikel ini membahas tentang relevansi pemikiran KH Imam Zarkasi tentang Pendidikan dalam mengembangkan intrapersonal inteligensi. Penelitian ini merupakan penelitian Pustaka dengan menggunakan metode deskriptif -kualitatif. Hasil dari penelitian ini menunjukkan bahwa pemikiran-pemikiran masih sangat relevan diterapkan dalam upaya mengembangkan intrapersonal inteligensi siswa. Diantara pemikirannya adalah; 1) pengembangan intrapersonal inteligesi dilakukan dengan dua acara; secara sengaja, yaitu 
melalui Pendidikan di Lembaga-lembaga formal, dan secara tidak sengaja yaitu melalui interaksi dengan lingkungan sekitar. 2) Metode pembelajaran untuk mengembangkan intrapersonal inteligensi dilakukan melalui Latihan individu; dengan mempercayakan kepada anak untuk melakukan tugasnya sendiri dengan penuh tanggungjawab, memberikan kesempatan kepada anak untuk membuat keputusan sendiri dan bertanggung jawab atas keputusannya., dan kegiatan lain yang serupa. Melalui lembaga yang dikembangkannya, yaitu Pondok Pesantren Gontor, KH Imam Zarkasi mengembangkan gagasan-gagasannya, antara lain; pelaksanaan pembelajaran melalui sistem klasikal, penggunakaan metode yang memungkinkan anak mengembangkan daya pikirnya secara kritis, independen, dan bertanggungjawab, dan memberikan kegiatan ekstrakurikuler sebagai sarana untuk mengembangkan diri.

Keywords: Education Thoughts, KH. Imam Zarkasyi, Intrapersonal Intelligence

\section{A. Pendahuluan}

Kemajuan suatu bangsa tidak hanya dilihat dari salah satu segi saja, akan tetapi juga dari segi-segi yang lain. Misalnya dari segi pembangunan nasional, utamanya dilihat dari segi Pendidikan. Di dalam pendidikan tidak hanya menekankan kecerdasan akal saja tetapi juga kematangan akal budi, Sejalan dengan hal tersebut Ki Hajar Dewantara menyatakan bahwasanya pendidikan merupakan suatu cara yang dapat digunakan dalam memajukan budi pekerti, pikiran serta jasmani anak agar dapat memberikan segala seuatu yang sempurna dalam hidup. ${ }^{1}$ Hal senada juga dinyatakan oleh Imam Zarkasyi menyatakan bahwa pendidikan Islam adalah menjadi proses pendidikan mengenai jiwa juga mentalnya guna membangun manusia atau dirinya sendiri secara merdeka. ${ }^{2}$ Begitu juga dengan pernyataan Omar Mohammad Al-Toumy bahwa pendidikan Islam sendiri merupakan suatu cara yang digunakan setiap individu maupun masyarakat sendiri dalam memperbaiki perilakunya dengan berlandaskan ajaran Islam dalam proses pendidikannya. ${ }^{3}$

1 Hadi Purnomo, Pendidikan Islam Integrasi Nilai-Nilai Humanis, Liberasi Dan Transendensi; Sebuah Gagasan Paradigma Baru Pendidikan, ed. Asnawan, Cetakan Ed (Yogyakarta: Absolute Media, 2016), 17.

2 Najwa Mu'minah, “Character Buliding Dalam Konsep Pendidikan Imam Zarkasyi Ditinjau Dari Filsafat Moral Ibnu Miskawaih,” Jurnal Filsafat 25, no. 1 (2015): 100-133.

${ }^{3}$ Subri, "Manusia Dan Pendidikan Islam," Jurnal Tarbawi Jurnal Pendidikan Islam 4, no. 2 (2017): 248. 
Intrapersonal intelegensi merupakan salah satu keahlian yang harus dikembangkan pada semua pelajar karena hal tersebut penting dan dapat dijadikan sebagai bekal dalam mengarungi kehidupannya. Dalam hal ini May Lwin dkk dalam bukunya How to Multiply Your Child's Intelligence menyatakan bahwasanya intrapersonal intelegensi merupakan kemampuan di dalam memahami atau mengetahui diri sendiri dan bertanggung jawab atas kehidupannya sendiri, serta mampu mengarahkan emosi mereka sendiri untuk memperkaya dan membimbing kehidupan mereka sendiri. ${ }^{4}$ Dengan demikian Pendidik dalam proses pendidikannya tidak boleh hanya berpusat pada pengembangan salah satu bidang kemampuan saja dengan mengabaikan kemampuan yang lain, tetapi seorang pendidik juga harus memperhatikan kemampuan-kemampuan yang lain termasuk dalam bidang intrapersonal intelligence. Hal ini dikarenakan nantinya kemampuan tersebut akan sangat berguna dalam membentengi dirinya untuk menghadapi tantangan nantinya.

KH Imam Zarkasi termasuk salah satu tokoh yang sangat peduli terhadap upaya pengembangan Intrapersonal intelegensi peserta didik. Dalam hal ini Rusli Takunas dalam sebuah artikelnya menyatakan bahwa KH. Imam Zarkasyi banyak melakukan upaya-upaya pembaharuan yang di antaranya meliputi beberapa dimensi, yaitu pembaruan sistem dan metode pendidikan, materi dan kurikulum, struktur dan manajemen, pola pikir, kebebasan Pendidikan, dan yang terpenting dari itu semua adalah Pendidikan jiwa. Hal ini dikarenakan, dengan jiwa itulah yang akan menentukan falsafah hidup para santrinya serta memelihara kelangsungan hidup pesantren tentunya. Beliau sempat membuat dan menyebut jiwa pesantren tersebut dengan sebutan Panca Jiwa Pondok, yaitu kesederhanaan, keikhlasan, kesanggupan membantu atau menolong dirinya sendiri, kekuatan iman dan spirituan (ukhuwah Islamiyah) serta mempunyai jiwa yang bebas. ${ }^{5}$

\footnotetext{
${ }^{4}$ Evi Muafiah, "Strategi Pembelajaran Multiple Intelligences di TK/RA Ponorogo," ThufuLA: Jurnal Inovasi Pendidikan Guru Raudhatul Athfal 4, no. 1 (2017): 66, https://doi.org/10.21043/thufula.v4i1.1977.

${ }^{5}$ Rusli Takunas, "Pemikiran Pendidikan Islam KH. Imam Zarkasyi," Scolae: Journal of Pedagogy 1, no. 2 (2018): 154-60.
} 
Tulisan lain berkaitan dengan hal di atas ditulis oleh Saifudin Alif Nurdianto dalam Jurnal Jantra dengan judul "KH. Imam Zarkasyi: Membangun Karakter Umat Dengan Modernisasi Pesantren (1926-1936)”. Menurutnya dalam pengembangan pesantren KHImam Zarkasyi juga mengembangakan yang disebut dengan Hidden Curriculum (Kurikulum Tidak Tertulis). Model kurikulum ini merupakan pengembangan dari kurikulum yang ada, dimana di dalamnya mencakup semua ruang gerak hidup peserta didik, mulai dari ketika ia berada di kamar tidur, di jalan, di tempat makan, di atas kendaraan, bersama orang tua, bersama seorang atau tamu, guru dan lainnya. Hasil daripada hidden curriculum ini tidak berbentuk angka yang tertulis di atas kertas, tetapi terlihat dalam perubahan pola pikir siswa yang direpresentasikan dalam kehidupan sosial kemasyarakat. Menurut KH. Imam Zarkasyi pengembangan hidden curriculum sebagai upaya dalam mendidik mentalitas dari pada santri. ${ }^{6}$

Berdasarkan beberapa kajian pustaka diatas, penulis berusaha mengambil topik penelitian dengan judul "Relevansi Pemikiran Pendidikan Imam Zarkasyi Dalam Pembentukan Intrapersonal Intelegensi Terhadap Generasi Alfa”. Alasan penulis mengangkat judul penelitian ini dikarenakan penulis menemukan adanya keterkaitan antara pemikiran Pendidikan KH. Imam Zarkasyi dengan pentingnya pembentukan intrapersonal intelegensi peserta didik. Selain itu, pembaharuan yang dilakukan Imam Zarkasyi adalah salah satu pemikiran yang cocok digunakan untuk melakukan pembaharuan Pendidikan di era generasi milineal saat ini. Oleh karena itu, berdasarkan paparan di atas, maka tujuan penelitian ini adalah untuk mengetahui relevansi pemikiran Pendidikan Imam Zarkasyi dalam pembentukan intrapersonal intelegensi di era generasi alfa. Metode penelitian yang digunakan dalam penelitian ini adalah penelitian kualitatif deskripstif dengan menggunakan jenis penelitian kepustakaan (library research). Teknik pengumpulan data dalam penelitan ini adalah dokumentasi dari naskah-naskah atau majalah yang bersumber dari khasanah kepustakaan. Oleh karena itu, dalam studi kepustakaan ini di dalamnya mencakup

${ }^{6}$ Saifuddin Alif Nurdianto, "K. H. Imam Zarkasyi: Membangun Karakter Umat Dengan Modernisasi Pesantren (1926-1936),” 2019, 181-90, https://doi.org/10.31227/osf.io/q738y. 
proses yakni mengidentifikasi teori secara runtut, penemuan pustaka serta menganalisis file yang ada kaitannya dengan topik penelitian. ${ }^{7}$

\section{B. Hasil dan Pembahasan}

\section{KH. Imam Zarkasyi dan pemikirannya terhadap Pendidikan}

\section{a. Biografi KH. Imam Zarkasyi}

KH. Imam Zarkasyi dilahirkan pada tanggal 21 Maret 1910 di Gontor Ponorogo Jawa Timur $^{8}$ dan menghembuskan nafas terakhirnya tepat di tanggal 30 Maret 1985. Zarkasyi meninggalkan seorang istri dan 11 anaknya yakni 6 pria dan 5 perempuan. Beliau merupakan putra bungsu dari ke tujuh anak. KH. R. Imam zarkasyi, R. Ahmad Sahal dan R. Zainuddin Fananie merupakan tiga bersaudara dari penerus pondok modern Gontor selanjutnya yakni dari tujuh saudara. Empat dari kakak tertuanya ini terdiri dari satu orang laki-laki yang bernama R. Rahmat Soekarto yang menjabat sebagai lurah Gontor dan tiga perempuan bernama Rr. Sumijah Harjodipuro, Rr. Sukadmi Ibn Hadjar, dan Rr. Sumilah Imam Ngulomo. ${ }^{9}$ Ayah KH. Imam Zarkasyi dikenal sebagai keturunan bangsawan dari tanah Jawa yang bernama Raden Santoso Anombesari. Selain itu, beliau juga sebagai generasi ketiga berdasarkan pimpinan Pondok Gontor pertama dan generasi kelima yakni putra dari Sultan Kesepuhan Cirebon yang bernama Pangeran Hadiraja Adipati Anom. Ibu KH. Imam Zarkasyi bernama Siti Partiyah, yang juga keturunan Bupati Suriadiningrat dan sangat terkenal di zaman Mangkubumen dan Penambangan. ${ }^{10}$

Sejak dari kecil tepatnya pada tahun 1918, Imam Zarkasyi telah menjadi anak yatim. Pada saat itu, ayah beliau meninggal dunia pada saat kondisi pondok

\footnotetext{
${ }^{7}$ Mestika Zed, "Metode Penelitian Kepustakaan," Cetakan Ke (Jakarta: Yayasan Pustaka Obor Indonesia, 2014), 2.

${ }^{8}$ Misbah, K.H. Imam Zarkasyi Dari Gontor: K.H. Imam Zarkasyi Dari Gontor (Kediri: Gontor Press 2009, 2009), 26.

${ }^{9}$ Perspektif Rahmatan and L I L Alamin, "Rahmatan Lil Alamin Journal of Peace Education and Islamic Study" 1, no. 1 (2018): 1-14.

${ }^{10}$ Moh. Nurhakim, "Imam Zarkasyi Dan Pembaharuan Pesantren: Rekonstruksi Aspek Kurikulum, Menejemen Dan Etika Pendidikan," Progresiva : Jurnal Pemikiran Dan Pendidikan Islam 7, no. 1 (2018): 1, https://doi.org/10.22219/progresiva.v7i1.7404.
} 
dalam keadaan sangat merosot dan belum mempunyai generasi penerus juga. Kemudian Siti Partiyah ibu dari KH. Imam Zarkasyi ini hanya mengasuh dan mendidik anak-anaknya sendirian. Berkat pendidikan yang diberikan oleh Ibunya KH. Imam Zarkasyi mendapatkan berbagai dasar suatu pendidikan, khususnya pendidikan dalam hal agama juga kecintaannya terhadap ilmu pengetahuan. $\mathrm{KH}$. Imam Zarkasyi juga selalu mengingat pesan yang selalu disampaikan oleh ibunya yang sangat dalam dan membekas itu. Di mana, Ibu beliau selalu mengatakan bahwa, "kamu harus menjadi alim dan salih". Akhirnya pesan tersebut tidak hanya diingat beliau, akan tetapi juga dilakukan oleh KH. Imam Zarkasyi. ${ }^{11}$

KH. Imam Zarkasyi mulai kecil hingga dewasa sudah berada dalam lingkungan keluarga pesantren. Setelah menginjak usia yang ke-16 tahun, KH. Zarkasyi memulai pendidikan pertamanya dalam pesantren, di mana pesantren tersebut tidak jauh dari tanah kelahirannya. Berbagai pesantren sudah pernah beliau singgahi, di antaranya pondok Joseran ${ }^{12}$, sekolah Ongko Loro di Jetis, pesantren Jamsaren di Solo $^{13}$. Pondok pesantren Jamsaren terkenal dengan kemampuan para lulusan dalam menghafal Alfiyah dan sebagai pelopor pengajaran al-Qur'an dan hadist. ${ }^{14}$ Masa kecilnya selama benar-benar beliau manfaatkan dengan optimal guna mencari pengetahuan serta mencari pengalaman yang sebanyak-banyaknya. Tidak berhenti dari situ saja, tapi KH. Imam Zarkasyi juga melanjutkan pendidikannya ke Padang Panjang Sumatra Barat yaitu di Tahawalib School yang beliau tempuh hingga tahun $1935 .{ }^{15}$

Selesainya sekolah Thawalib School, Imam Zarkasyi meneruskan pendidikannya di Normal Islam School atau Kulliyyatul Mu'allimin al-Islamiyah. Pendidikan tersebut didirikan oleh Persatuan Guru Agama Islam (PGAI) di Padang.

\footnotetext{
${ }^{11}$ Nurhakim, 84.

${ }^{12}$ Nurhakim, 85.

${ }^{13}$ Nurhakim, 85.

14 Ahmad Choirul Rofiq, "Perspektif K.H. Imam Zarkasyi Mengenai Kesatuan Ilmu Pengetahuan," Ta'allum: Jurnal Pendidikan Islam 6, no. 2 (2018): 313-46, https://doi.org/10.21274/taalum.2018.6.2.313-346.

${ }^{15}$ Rofiq, 322.
} 
Di sinilah Imam Zarkasyi mendapatkan ilmu serta dapat memperdalam teori pengajaran bahasa (selain ilmu pendidikan) melalui metode langsung. ${ }^{16}$ Setelah beliau tamat belajar di tempat tersebut, beliau diminta oleh seorang gurunya yang bernama Mahmud Yunus untuk menjadikan seorang direktur di perguruan tersebut. Tetapi KH. Imam Zarkasyi hanya bisa memenuhi sebuah permintaan serta kepercayaan yang telah diberikan oleh gurunya tersebut hanya satu tahun saja. Selanjutnya Imam Zarkasyi diminta kakaknya untuk pulang serta meneruskan perjuangan dalam mengamalkan ilmunya di Gontor saja. Hal ini dikarenakan pak Zar sapaan akrab dari KH. Imam Zarkasyi ini adalah salah satu yang diharapkan meneruskan pesantren tersebut. Akhirnya, KH. Imam Zarkasyi dipersilahkan Mahmud Yunus untuk mengabdikan dirinya ke Gontor. ${ }^{17}$

Selain mengabdikan dirinya di Pondok Pesantren Modern Gontor dalam bidang pendidikan, Imam Zarkasyi juga berkiprah di bidang kegiatan sosial kemasyarakatan dan kenegaraan. Tepatnya pada tahun 1943 beliau menjadi kepala Kantor Agama Karesdinenan Madiun. Selain itu, pada masa pendudukan Jepang beliau juga ikut serta membina dan menjadi seorang guru di barisan Hizbullah di Cibarusa Jawa Barat. Bahkan ketika negara Indonesia sudah merdeka, Imam Zarkasyi turut berperan aktif sebagai pembina di Departemen Agama RI, khususnya di Direktorat Agama di kala itu dipimpin oleh menteri H. M Rasyidi. Bukan hanya itu saja, keahlian yang dimilikinya tersebut juga sangat diperlukan di Departemen Pendidikan dan Kebudayaan yang kala itu menterinya Ki Hajar Dewantara. ${ }^{18}$ Dan masih banyak lagi jabatan penting lainnya.

Di tengah-tengah kesibukannnya dalam kegiatan sosial kemasyarakatan, beliau terbukti sangat konsisten dengan tidak meninggalkan disiplin keilmuannya yakni sebagai pemikir pembaharu pendidikan Islam di Indonesia sekaligus melaksanakan pembaharuan tersebut. Di bawah ini merupakan beberapa bukti karya-

\footnotetext{
${ }^{16}$ Rofiq, 322.

${ }^{17}$ Nurhakim, "Imam Zarkasyi Dan Pembaharuan Pesantren : Rekonstruksi Aspek Kurikulum, Menejemen Dan Etika Pendidikan," 85.

18 Nurhakim, 85.
} 
karya ilmiah yang ditulis oleh KH. Imam Zarkasyi, di antaranya sebagai berikut: ${ }^{19}$

1) Durus al-Lughah al-'arabiyyah I \& II.

2) Pembelajaran Tajwid, dalam bahasa Indonesia.

3) Ilmu Tajwid, dalam bahasa Arab.

Dari sekian banyak tokoh yang ada pada saat itu, KH. Imam Zarkasyi termasuk salah satu tokoh ulama pembaharu dalam pendidikan Islam serta salah satu tokoh mempunyai perhatian sangat besar bagi perkembangan pesantren di Indonesia. Setelah pulang dari Gontor KH. Imam Zarkasyi sungguh-sungguh mengabdikan dirinya hanya untuk membangun pondok pesantren dan menjaga peninggalanpeninggalan leluhurnya. ${ }^{20}$

Uraian beberapa hal di atas juga membuktikan bahwa sosok Imam Zarkasyi merupakan pribadi yang sangat jangkep (lengkap). Maksudnya, beliau tidak hanya sebagai seorang guru, melainkan sebagai pemimpin, pemikir sekaligus pelaksana ide-ide pembaharuan sebagai bentuk yang real atau nyata. Tidak hanya itu saja, sosok beliau juga merupakan seseorang yang dipandang sebagai seorang yang generalis. ${ }^{21}$ Yang mana dari berbagai displin ilmu ia juga menguasai jenis ilmu pengetahuan, namun dengan melihat karyanya yang ditulis untuk kepentingan pendidikan di Pondok Modern Gontor, beliau tampaknya memiliki spesialisasi di bidang di bidang Ilmu al-Qur'an dan bahasa Arab.

\section{b. Pemikiran KH. Imam Zarkasyi tentang Pendidikan}

Pendidikan memiliki peranan penting untuk mendukung keberhasilan seseorang di dalam meraih suatu kesuksesan. Hal ini sesuai dengan pernyataan Imam Zarkasyi bahwasanya Pendidikan adalah salah satu bagian terpenting untuk kehidupan sekaligus cara yang dapat digunakan untuk memajukan umat Islam. Oleh karena itu, banyak upaya yang sudah dilakukan Imam Zarkasyi dalam rangka

\footnotetext{
${ }^{19}$ Nurhakim, 86.

${ }^{20}$ Mohammad Aufin, "Kontribusi K.H Imam Zarkasyi Dalam Pemikiran Pendidikan Islam (Pesantren)," Journal of Chemical Information and Modeling 53, no. 9 (2019): 131-47.

${ }^{21}$ Umar Bukhory, "KH. Imam Zarkasyi Dan Genre Baru Pondok Pesantren (Refleksi Seorang Cucu Murid)," Journal of Islamic Studies 1, no. 2 (2016): 259-72.
} 
memajukan Pendidikan utamanya pondok pesantren. Menurut beliau, dahulu pesantren mempunyai beberapa kelemahan signifikan yaitu tidak memiliki tujuan Pendidikan, seharuskan disertakan pada langkah-langkah program yang ada di suatu pesantren tersebut. Dari zaman dahulu, Pendidikan selalu berjalan seakanakan hanya mengikuti arus yang ada dalam hal ini adalah keahlian-keahlian yang dimiliki sang kyai. ${ }^{22}$

Berkenaan dengan pernyataannya tersebut, beliau akhirnya merumuskan tujuan pesantrennya seperti ini: “yang jelas cukup dengan satu saja, yakni agar menjadi orang, hal itu sifatnya umum dan tidak menjurus, sehingga tidak bisa dikatakan dikatakan sebagai calon dokter, kusir, dan apa-apa. Katakan calon manusia. Manusia itu kerjanya apa? Dari Pendidikan yang telah diberikan itu mereka dapat mengetahui nantinya ia di masyarakat akan menjadi apa dan apa yang akan dikerjakannya nanti. Jadi, diperlukan adanya persiapan sebelum masuk di masyarakat dan tidak diperuntukkan di tingkat perguruan tinggi. Oleh karena itu, kami menamainya dengan pendidikan kemasyarakatan dan itu sangat diutamakan". Dalam hal ini, pembaharuan yang dilakukan oleh KH. Imam Zarkasyi ini berdasarkan adanya beberapa kelemahan yang ada pada pesantren pesantren di masa lalu. Sehingga dengan adanya kelemahan tersebut, Zarkasyi dapat mengatasinya dengan membuat tujuan serta menekankan pendidikan pesantren yang diarahkan. ${ }^{23}$ Pembaharuan ini dilakukan karena menurut beliau pendidikan sangat penting.

Pentingnya pendidikan ini juga mendorong pemerintah selalu melakukan suatu perubahan kurikulum untuk mengakomodasikannya dengan kebutuhan dari peserta didik. Kendala utama yang ada di dunia pendidikan adalah banyaknya instansi-instansi pendidikan yang sampai saat ini masih menerapkan pola pikir tradisional di dalam menjalankan proses belajar mengajar. Pendidikan bagi Imam

${ }^{22}$ Imroatul Fatihah, "Kepemimpinan KH. Imam Zarkasyi Di Pondok Modern Darussalam Gontor," JIEM (Journal of Islamic Education Management) 2, no. 2 (2018): 26, https://doi.org/10.24235/jiem.v2i2.3407.

${ }^{23}$ Fatihah, 28. 
Zarkasyi menjadi proses pendidikan jiwa dan mental untuk membangun manusia atau dirinya sendiri secara merdeka. Konsep pendidikannya merupakan pembaharuan kritis, khususnya terhadap pendidikan feodalisme. ${ }^{24}$ Oleh karena itu, KH. Imam Zarkasyi melakukan Pembaharuan pendidikan Islam yang terbagi menjadi empat kelompok. Diantaranya yakni, dalam bidang metode dan sistem pendidikan, struktur dan manajemen pesantren, kurikulum pesantren serta pola pikir santri dan kebebasan pesantren. ${ }^{25}$

Berikut ini merupakan pembaharuan-pembaharuan yang dilakukan $\mathrm{KH}$. Imam Zarkasyi dalam Pendidikan:

a. Pembaharuan Sistem dan Metode Pendidikan

KH. Imam Zarkasyi mengimpelementasikan sistem pendidikan klasikal yang dipandu secara terorganisir pada bentuk penjenjangan kelas pada jangka waktu yang sudah ditentukan. Maksud dari ini adalah dengan menerapkan efisiensi pada pengajaran, dengan harapan waktu yang tidak lama bisa memunculkan suatu hasil yang besar dan berkualitas. Selain menerapkan sistem cara klasikal, beliau juga memperkenalkan kegiatan ekstrakulikuler. Dalam kegiatannya dilakukan di lain waktu jam pembelajaran berlangsung seperti halnya, kesenian, olahraga, pidato dalam tiga bahasa (Indonesia, Arab dan Inggris), keterampilan, organisasi pelajar dan pramuka. Kegiatan tersebut digunakan sebagai wadah para santri untuk mengembangkan diri agar mempunyai berbagai skill. ${ }^{26}$

Keefektifitasan pengajaran yang dilakukan secara klasikal ini juga diakui oleh Mumtani`ah. Menurutnya pelaksanaan Pendidikan secara klasikal ini sangat cocok digunakan di pesantren di zaman modern ini. Hal ini ditunjukkan dalam penelitiannya yang dilakukan pada pondok An-Nur Rejosari, Pakis, Kota Magelang. Dalam kesimpulannya ia menyatakan bahwa pelaksanaan pengajaran kitab kuning yang dilakukan secara klasikal dan berjenjang sangat efektif dan

\footnotetext{
${ }^{24}$ Mu'minah, "Character Buliding Dalam Konsep Pendidikan Imam Zarkasyi Ditinjau Dari Filsafat Moral Ibnu Miskawaih," 110.

${ }^{25}$ Takunas, "Pemikiran Pendidikan Islam Kh. Imam Zarkasyi," 157-59.

26 Takunas, 154.
} 
memudahkan para santri. ${ }^{27}$

Selanjutnya KH. Imam Zarkasyi juga menegaskan bahwa meskipun terdapat kesamaan antara sistem asrama dan sistem klasikal, beliau tidak membuang satu hal yang sangat berguna dan harus ada serta sudah menjadi adat di dalam pendidikan pondok pesantren yakni mempelajari berbagai kitab klasik atau biasa disebut kitab gundul/kuning. Beliau mengarahkan semua santri agar mempunyai, memahami dan membaca kitab yang ada di ponpes salafiyah untuk dikajinya. ${ }^{28}$

Begitu juga di dalam metode pembelajaran, Imam Zarkasyi menekankan kepada para pendidik untuk menggunakan berbagai metode dan kaidah pedagogi dalam proses pembelajaran di sekolah. Misalnya pembelajaran tersebut wajib diawali dari yang lebih mudah menuju ke yang lebih sulit, tidak terburu-buru untuk berpindah ke materi yang lain sebelum pelajar memahami dengan betul pembelajaran yang sudah diajarkan, proses pembelajaran wajib sistematik dan teratur, memperbanyak berlatih apabila selesai pembelajaran dan sebagainya, kaidah itu bisa diterapkan oleh semua guru dengan syarat bahwa pengajar terlebih dahulu wajib memiliki keahlian terkait metode pengajaran. Menurut pandangan KH. Imam Zarkasyi metode itu jauh sangat penting dari pada materi, serta kepribadian seorang pendidik itu juga tidak kalah pentingnya dibandingkan metode tersebut. ${ }^{29}$

Selain itu dalam belajar bahasa Arab atau Inggris, Zarkasyi menyadari akan pentingnya metode dan strategi mengajar. Beliau menemukan metode Berlitz yang menurutnya sesuai yang dikenal dengan istilah (Metode Langsung), dalam bahasa Arabnya dikenal sebagai Thariqah Mubasharah. Adanya metode tersebut, membuat para siswa yang belajar bahasa asing bisa dapat berkomunikasi secara

${ }^{27}$ Mumtani'ah, "Pembaharuan Sistem Pendidikan Di Pesantren (Studi Kasus Di Pondok Pesantren An-Nur Rejosari, Pakis, Magelang)," Al-Insyiroh: Jurnal Studi Keislama EDUGAMA: Jurnal Kependidikan Dan Sosial Keagamaan 5, no. 1 (2019): 182, https://doi.org/10.35309/alinsyiroh.v6i1.3819.

${ }^{28}$ Takunas, "Pemikiran Pendidikan Islam Kh. Imam Zarkasyi," 158.

${ }^{29}$ Takunas, 158 
langsung dalam bahasa yang sedang dipelajarinya. ${ }^{30}$

Dari penjelasan di atas bahwa KH. Imam Zarkasyi mengemukakan adanya sistem pendidikan dengan diterapkannya efisiensi waktu pembelajaran dengan relatif memiliki waktu relatif sedikit. Akan tetapi menghasilkan produk yang lebih besar dan bermutu. Serta metode pembelajaran yang baik berawal dari gabungan antara pemahaman yang baik terhadap pola pengajaran dan pemahaman terhadap kondisi anak didik.

Menurut Imam Zarkasyi terdapat sembilan metode pembelajaran di antaranya sebagai berikut. ${ }^{31}$

1) Pembelajaran seharusnya dimulai dari yang mudah terlebih dahulu baru ke yang sederhana.

2) Dalam pemindahan ke pelajaran yang lain sebelum anak didik dapat mengetahui dengan benar pelajaran yang sudah diberikan siswa tidak bisa melanjutkan pada pembelajaran selanjutnya. Hal ini membuktikan bahwa tidak adanya tergesa-gesa dalam pemindahan ke pelajaran lain.

3) Proses pedagogi harus dengan teratur dan sistematik.

4) Memperbanyak latihan jika selesai pembelajaran.

5) Guru tidak boleh memiliki rasa bosan untuk melakukan pengulangan pelajaran dengan soal-soal evaluasi.

6) Hendaknya menjadi pengajar yang pintar-pintar untuk mengetahui dan mengukur kemampuan dan kondisi atau syarat kepribadian siswa.

7) Hendaknya menjadi pengajar yang pintar-pintar menarik perhatian siswa dengan memberikan latihan-latihan dan ulangan-ulangan yang bervariasi.

8) Hendaknya sebagai guru selalu memberikan motivasi kepada siswa yang pintar dan tidak meremehkan siswa yang lemah.

9) Hendaknya sebagai guru memperhatikan tingkat perbedaan atau kecerdasan

\footnotetext{
${ }^{30}$ Takunas, 158.

${ }^{31}$ Dwi Budiman Assiroji, “Konsep Pendidikan Islam Menurut KH. Imam Zarkasyi,” Jurnal
} Bina Ummat 1, no. 1 (2018): 41. 
dan kelemahan pada individu siswa.

Dari sini dapat disimpulkan, bahwa KH. Imam Zarkasyi berani melakukan pembaharuan terkait sistem dan metode Pendidikan serta menentang sistem Pendidikan kolonial yang selama ini banyak mempengaruhi pendidikan di Indonesia. Pemikiran dari beliau ini membawa banyak keunggulan jika dibandingkan sistem pendidikan yang ada. Keunggulan tersebut dapat dilihat dari kemodernan sistem yang diterapkannya, bahwasanya kemodernan bukan hanya dapat ditonjolkan dari segi fasilitas. Di sini modern yang dimaksud adalah modern dalam hal sistem, konsep, dan metodenya. Keunggulan tersebut dapat dijabarkan sebagai berikut yakni pertama, pengelompokkan siswa dengan kelas sesuai potensi yang dimiliki siswa. Kedua, adanya penguasaan dasar-dasar bahasa. Ketiga, asrama tersebut dapat diisi dengan kapasitas besar. Keempat, pengajaran kitab kuning dengan menggunakan metode yang berbeda. Kelima, kurikulum 100\% umum dan $100 \%$ agama. Keenam, beliau berhasil dalam mengintegrasikan tiga dimensi pendidikan yakni lingkungan keluarga, masyarakat dan sekolah. Ketujuh, menggunakan metode pengajaran yang sangat bervariatif. Ke delapan, penciptaan, learning by instruction, pembiasaan, learning by doing, kritik, dan kepemimpinan. Kesembilan, pengembangan sistem belajar 24 jam dengan adanya pengawasan yang dilakukan melalui kegiatan santri dalam hal kepemimpinan, organisasi pelajar, organisasi kepramukaan dan kegiatan kemahasiswaan. ${ }^{32}$

b) Pembaharuan Materi dan Kurikulum Pendidikan

Konsep kurikulum dari pendidikan yang diberikan oleh KH. Imam Zarkasyi yakni pelajaran umum 100\% dan agama juga 100\%. Selain itu, pelajaran Hadist, Tafsir, Ushul Fiqih, Fiqih, yang selalu diajarkan di pondok pesantren yang tradisional, KH. Imam Zarkasyi juga memberikan tambahan ke dalam kurikulum suatu lembaga pendidikan yang sedang dikelola saat ini dengan adanya ilmu pengetahuan umum, misalnya Ilmu Alam, Ilmu Hayat, Ilmu Pasti (berhitung,

\footnotetext{
${ }^{32}$ Assiroji, 41.
} 
Aljabar dan Ilmu Ukur), sejarah, tata negara, ilmu bumi, ilmu pendidikan, ilmu jiwa dan sebagainya. Pelajaran seperti Bahasa Arab dan Bahasa Inggris, sebagai karakteristik spesial dari pondok pesantren tersebut. Selain itu, kepribadian dan moralitas tercapai perlu adanya dukungan, supaya peserta didik dapat menerima pendidikan kemasyarakatan kemasyarakatan dan sosial yang bisa digunakan dalam berlangsungnya kehidupan dari segi sosial dan pekonominya. Adanya latihan praktis yang akan memberikan gambaran yang jelas terhadap kehidupan di masyarakat. Selain itu memberikan pengajaran ekstra seperti etika atau tata krama yang berupa kesopanan lahir dan kesopanan batin merupakan hal yang wajib diajarkan termasuk dari tingkah laku, gerak-gerik hingga cara berpakaian. Dalam kegiatan inilah para santri atau peserta didik dilatih berbagi cinta kasih yang mendahulukan kesejahteraan beserta buat pribadinya, kesadaran, pengorganan yang diabadikan demi kesejahteraan masyarakat, khususnya umat Islam. ${ }^{33}$

Dari penjelasan di atas bahwa KH. Imam Zarkasyi menghendaki dihapuskannya dikotomi ilmu yang kemudian mendirikan lembaga yang integral. Maksudnya adalah sebuah lembaga yang mengintregasikan antara ilmu agama dan ilmu umum. Menurutnya, sebab dalam Islam semua ilmu adalah sama, hanya saja bedanya yang satu dihasilkan dari telaah terhadap al-Qur'an dan as-sunnah sementara yang satu adalah hasil dari penelitian terhadap alam. Dari pengajaran yang diberikan secara praktis dan ekstra tersebut dapat menumbuhakan kesadaran akan rasa cinta kasih, mendahulukan yang lebih penting baik kesejahteraan orang lain dan tentunya dirinya sendiri, tingkah laku, gerak-gerik hingga cara berpakaiannya, hal ini akan menjadikan santri atau peserta didik paham akan dirinya sendiri dengan lingkungan sekitar. ${ }^{34}$

c) Pembaharuan Struktur dan Manajemen

Pemikiran KH. Imam Zarkasyi berkenaan dengan struktur dan manajemen telah memunculkan modernisasi pesantren yaitu dengan mewakafkan pesantren.

\footnotetext{
33 Takunas, "Pemikiran Pendidikan Islam Kh. Imam Zarkasyi," 158.

34 Takunas, "Pemikiran Pendidikan Islam Kh. Imam Zarkasyi."
} 
Awal mulanya beliau memunculkan struktur manajemen ini karena pada saat ia mengunjungi Universitas Al-Azhar, Mesir yang terkenal akan mewakafkan dan langgengnya. Al Azhar awal mulanya hanya sebuah tempat ibadah yang sangat sederhana tetapi bisa digunakan selama berates tahun tahun dan sudah mempunyai wakaf yang dapat memberikan dana gratis untuk para pelajar di seluruh dunia yang ingin belajar di sana. Kedua, kunjungannya ke pondok pesantren Syanggit di Afrika Utara letaknya di dekat Libya. Yang terkenalnya dari lembaga ini yaitu atas kedermawaan dan keikhlasan pengasuhnya. Bahwa pesantren yang dikelola dengan ikhlas ini dan tanpa mengharap imbalan apapun serta mendidik muridnya, dan memiliki tanggungan atas keperluan hidupnya. Ketiga, Universitas Muslim Aligarch yang merupakan universitas dengan membekali wawasan mahasiswa pengetahuan umum dan agama sehingga mereka memliki ilmu yang luas dan menjadi pencetus kebangkitan Islam di India. Keempat, Perguruan Shantiniketan yang berada di India merupakan perguruan yang didirikan oleh seorang filosof Hindu, yaitu Rabendranath Tagore. Perguruan tinggi ini terkenal akan kedamaiannya walaupun letaknya yang relatif jauh dari keramaian, akan tetapi pelaksanaan pendidikannya sangat baik dan bahkan dapat mempengaruhi dunia. Dalam memimpin Pesantren Gontor, Imam Zarkasyi dan kedua kakaknya mewakafkan Pesantren Gontor kepada umat Islam. ${ }^{35}$

Dari pengalaman inilah kemudian KH. Imam Zarkasyi menemukan idenya mengenai Badan Wakaf yang merupakan terbosan baru dalam manajemen pengelolaan pondok pesantren. Ide ini ingin merubah adanya kebiasaan pesantren dari dahulu mempunyai sistem turun-temurun yakni di mulai dari kyai kemudian anak-anaknya, cucu-cucunya sampai seterusnya. Dalam memimpin Pesantren Gontor, Imam Zakasyi dan kedua kakaknya mewakafkan Pesantren Gontor kepada umat Islam. ${ }^{36}$ Saat ini pimpinan dari PonPes Modern Gontor ini menaungi berbagai lembaga Pendidikan yang diantaranya, 1) Pengasuhan Santri, 2) Yayasan

\footnotetext{
${ }^{35}$ Takunas.

36 Takunas.
} 
Pemeliharan dan Perluasan Wakaf Pondok, 3) Kulliyat Al-Mu.alimin Al-Islamiyah (KMII), 4) Ikatan Keluarga Pondok Modern (ISID), dan 5) Institut Studi Islam Darussalam. ${ }^{37}$

d) Pembaharuan Pola Pikir dan Kebebasan

Berkenaan dengan hal ini, KH Imam Zarkasi menekankan tentang pentingnya menanamkan sikap independesi. Para santri harus melatih untuk mengurus segala kepentingannya sendiri serta memiliki kebebasan dalam memilih jalan hidupnya sendiri sebagai bekal kehidupan di masyarakat nanti. Gagasan independen ini terealisasi dengan terciptanya Pondok Gontor yang sangat bersih jauh dari kepentingan-kepentingan politik dan kelompok organisasi apapun. ${ }^{38} \mathrm{KH}$. Imam Zarkasyi menginginkan tidak adanya kepentingan politik atau golongan apapun dalam bidang pendidikan. Lembaga pendidikan wajib independen serta bertanggung jawab atas pihak yang lainnya. Oleh karena itu, perlunya menanamkan jiwa berdikari untuk dapat bersikap netralis dan moderat dalam mempimpin sesuatu apapun.

Gagasan Imam Zarkasi ini selaras dengan pandangan yang beberapa penulis lainnya. Rusdi Sulaiman sebagai misal menyatakan bahwa jiwa mandiri, ikhlas, netral, moderat dan bertanggung jawab perlu ditanamkan kepada para santri untuk mendidik mereka agar berani berbuat, berkreasi dan sekaligus bertanggung jawab atas yang dilakukannya baik dalam kehidupannya di lingkungan pondok dan ketika nanti mereka telah hidup bermasyarakat. ${ }^{39}$ Sejalan dengan hal tersebut Mohamad Salik dalam sebuah artikelnya menyatakan, penanaman nilai-nilai Islam secara moderat dan pembiasaan karakter-karakter peduli sangat diperlukan apalagi di masa sekarang ini, di tengah-tengah bermunculan paham-paham radikalisme. Dengan menanamkan nilai-nilai keislaman yang moderat kepada para santri

${ }^{37}$ Takunas.

${ }^{38}$ Takunas.

${ }^{39}$ Rusydi Sulaiman, "Hakikat Pendidikan Pesantren : Studi Atas Falsafah, Idealisme, Dan Manajemen Pendidikan Pondok Pesantren Al Islam Kemuja Mendobarat Bangka," EDUGAMA: Jurnal Kependidikan Dan Sosial Keagamaan 5, no. 2 (2019): 12. 
diharapkan akan mampu menangkal tumbuhnya gerakan radikalisme yang berkembang akhir-akhir ini. ${ }^{40}$

\section{Pembentukan Intrapersonal Intelegences}

Tokoh pencetus teori multiple intelligences adalah Howard Gardner. Menurut Howard Gardner, inteligensi merupakan kemampuan-kemampuan yang digunakan dalam memecahkan persoalan serta menghasilkan produk dalam suatu setting yang bermacam-macam dan pada situasi yang nyata. Sejalan dengan pendapat tersebut dinyatakan oleh Stern bahwa intelegensi merupakan kecakapan dalam menyelaraskan diri secara sederhana dengan situasi yang baru dengan memanfaatkan bekal pikiran yang sudah ada berdasarkan tujuannya. ${ }^{41}$

Menurut Howard Gardner ada sembilan intelegensi yang dimiliki setiap anak, salah satunya yaitu intelegensi intrapersonal/ kecerdasan intrapersonal. ${ }^{42}$ Kecerdasan intrapersonal (intrapersonal intelligences) merupakan suatu kemampuan yang berkaitan dengan pengetahuan yang ada di dalam dirinya sendiri dan kemampuan dalam melakukan sesuatu secara adaptatif berdasarkan pengenalan diri. Dalam kecerdasan intrapersonal yang bisa dikembangkannya antara lain, bercakap-cakap, aktualisasi diri berdasarkan perasaan, keyakinan diri, memuja-muja diri sendiri dan mengontrol emosi. ${ }^{43}$

Kecerdasan tidak hanya terkait akan hal-hal dengan penerapan kemampuan dan penguasaan saja, akan tetapi juga terkait pembentukan kemampuan yang

40 Mohamad Salik and Ali Mas'ud, "Pesantren Dan Upaya Menangkal Tumbuhnya Radikalisme: Analisis Gagasan KH. Marzuki Mustamar," Jurnal Pendidikan Agama Islam (Journal of Islamic Education Studies) 8, no. 1 (2020): 8-9, https://doi.org/10.15642/jpai.2020.8.1.1-20.

${ }^{41}$ Habibah, "Penerapan Strategi Multiple Intelligences Pada Mata Pelajaran Pendidikan Agama Islam (Studi Kasus Di SMP Negeri 3 Sungailiat)," Edugama: Jurnal Kependidikan Dan Sosial Keagamaan 5, no. 1 (2019): 63, https://doi.org/10.32923/edugama.v5i1.959.

42 S.W Utami, "Multiple Intelligences: Platform Global Paling Efektif Untuk Pendidikan Abad Ke-21 Dalam Pendidikan Dan Pembelajaran," Prosiding Seminar Nasional \& Call Paper Psikologi Pendidikan 2019, no. April (2019): 251-57.

${ }^{43}$ Mustika Arif Jayanti and Achmad Maulana Malik Jamil, "Hubungan Multiple Intelligences Pada Unsur Intrapersonal Dengan IPK Mahasiswa Pendidikan Geografi Universitas Kanjuruhan Malang," Jurnal Pendidikan Geografi 24, no. 2 (2019): 119-31, https://doi.org/10.17977/um017v24i22019p119. 
dimilikinya. Sehingga nantinya dapat dimanfaatkan dalam kehidupan sehari-hari. Terkait dalam hal pembentukan itu sendiri memiliki pengertian segala keadaan di luar diri seseorang yang dapat mempengaruhi perkembangan intelegensi. Dalam hal ini cara membentuk intrapersonal intelegensi dapat dibedakan menjadi dua yaitu pembentukan secara sengaja seperti yang dilakukan di sekolah-sekolah dan pembentukan tidak sengaja seperti adanya pengaruh alam sekitar. ${ }^{44}$ Untuk membentuk Kecerdasan intrapersonal cara belajar terbaik adalah dengan melatih setiap anak untuk dapat tekun dan bertanggung jawab atas tugasnya, serta mempercayakan anak terhadap tugas-tugas tertentu. ${ }^{45}$ Penerapan lainya juga dapat dilakukan dengan memberi kesempatan kepada anak untuk ketetapan keputusan, kegiatan dan pandangan lainnya dalam kegiatan sehari-hari. Kegiatan bisa dilakukan antara lain: ${ }^{46}$

\section{Membuat Rencana Untuk Esok Hari}

Sebelum tidur, peserta didik dapat menggambarkan kegiatan yang akan dilakukannya di kemudian hari. Dapat membuat daftar kegiatan dan membayangkan apa yang dilakukan dalam kegiatan pada jadwal tersebut.

\section{Mengevaluasi Pencapaian Hari Ini}

Sebelum tidur, menyempatkan berpikir dan intropeksi diri atas pencapaian yang telah didapat pada saat ini. Memutas kembali peristiwa atau serta memikirkan dampak baik buruknya serta mengambil keputusan yang harus dilakukan supaya tidak terdapat hal buruknya. Sejalan dengan penjelasan di atas, terdapat juga beberapa hal yang bisa dilaksanakan oleh pengajar dalam membentuk kecerdasan intrapersonal, yaitu seperti cara pengajaran yang dilakukan guru harus menarik dan tidak monoton, memanfaatkan kegiatan belajar mengajar di luar kelas sehingga

${ }^{44}$ Hanisah, "Meningkatkan Kecerdasan Intrapersonal Anak Melalui Kegiatan Berceritera Berbantuan Media Film/VCD Di Kelompok B5 RA Ummatan Wahidah Di Kota Curup" (Universitas Bengkulu, 2014), 30.

45 Ayunda Pinanti Kasih, "9 Jenis Kecerdasan Anak Dan Cara Mengembangkannya," Kompas.com, 2020.

${ }^{46}$ Ina, “Kecerdasan Intrapersonal,” Dosen Psikologi.com, 2019. 
pembelajaran tidak hanya terbuang di dalam kelas saja. ${ }^{47}$ Kegiatan yang dilakukan di sekolah seperti menciptakan membentuk image yang positif seperti pengajar bisa memberikan kesan pribadi yang baik pada pelajar dengan memunculkan sikap yang hangat namun tetap tegas pada pelajar sehingga ia tetap dapat memiliki hormat pada pengajar serta menciptakan suasana yang mendukung pembentukan intrapersonal dan penghargaan diri anak. ${ }^{48}$

\section{Relevansi Pemikiran KH. Imam Zarkasyi Dalam Pembentukan Intrapersonal Intelegensi}

Di era sekarang ini terdapat berbagai tantangan yang harus dihadapi dalam dunia pendidikan. Tantangan-tantangan tersebut antara lain adalah adanya globalisasi, kebutuhan terhadap generasi yang unggul, jumlah penduduk di usia muda meningkat drastis dengan cukup besar sehingga menuntut pola pengajaran yang baru. ${ }^{49}$

Melihat berbagai tantangan dunia pendidikan, banyak tokoh-tokoh muslim di Indonesia khususnya dalam bidang pendidikan Islam yang melakukan pembaharuan, salah satunya adalah KH. Imam Zarkasyi. Seseorang yang berkecimpung di dalam Pondok Pesantren Modern Gontor. Beliau merupakan seorang pendidik sekaligus seorang yang ahli dalam bidang pendidikan. KH. Imam Zarkasyi sangat paham betul terkait pentingnya penggunaan metode dan strategi mengajar. Oleh karena itu, beliau telah mengemukakan pemikiran-pemikirannya dalam memajukan pendidikan Islam terutama dalam pesantren. Hal ini dilakukan beliau agar sebuah pesantren dapat menghadapi tantangan dalam dunia pendidikan di era generasi alfa.

Salah satu cara yang paling utama dilakukan oleh beliau dalam

${ }^{47}$ Hanisah, "Meningkatkan Kecerdasan Intrapersonal Anak Melalui Kegiatan Berceritera Berbantuan Media Film/VCD Di Kelompok B5 RA Ummatan Wahidah Di Kota Curup,” 31.

${ }^{48}$ Hanisah, 31.

49 Tatik Widyaningsih, "Revolusi Industri 4.0 Dan Pendidikan Anak Usia Dini Untuk Generasi Alfa: Sebuah Telaah," Prosiding Seminar Nasional Pendidikan FKIP 2, no. 1 (2019): 31819. 
menghadapai tantangan di era generasi alfa yakni dengan membentuk intrapersonal intelegensi. Dalam hal ini, teori di atas sudah menjelaskan bahwasanya terdapat dua hal yang dapat dilakukan dalam membentuk Kecerdasan Intrapersonal yaitu pembentukan sengaja seperti sekolah dan pembentukan tidak sengaja seperti adanya pengaruh alam sekitar.

Selaras dengan teori tersebut, langkah awal yang dilakukan Imam Zarkasyi dalam membentuk intrapersonal intelegensi yakni lebih mengarahkan kepada sistem pendidikan klasikal, metode pendidikan dan kegiatan ekstrakulikuler. Di sini KH. Imam Zarkasyi telah mengimplementasikan sistem pendidikan klasikal yang terpimpin secara terarah dalam bentuk penjenjangan kelas dalam jangka waktu yang sudah ditentukan. Maksud dari ini adalah dengan menerapkan efisiensi dalam pengajaran, serta dengan harapan waktu yang tidak lama dapat menghasilkan hal yang besar dan berkualitas. Selain menerapkan sistem klasikal tersebut, beliau juga memperkenalkan berbagai kegiatan ekstrakulikuler. Kegiatan-kegiatan ekstrakuler tersebut dilakukan di luar jam pelajaran, misalnya seperti: olahraga, keterampilanketerampilan, pramuka, pidato menggunakan tiga bahasa (Bahasa Indonesia, Bahasa Arab dan Bahasa Inggris), kesenian, dan berbagai organisasi yang ada di sekolah. Hal ini digunakan wadah para santri untuk mengembangkan diri agar mempunyai berbagai skill. ${ }^{50}$

Dengan menerapkan sistem Pendidikan klasikal dan menyediakan berbagai kegiatan ekstrakulikuler ini dikarenakan agar setiap guru dapat memahami terkait adanya perbedaan potensi- potensi, kemampuan-kemampuan dan keahlian yang dimiliki setiap peserta didik. Jadi, setiap anak dapat menentukan jalan hidupnya sendiri sesuai dengan keinginan masing-masing dan kemampuan yang ada di dalam diri anak. Selain itu, pendidik juga harus yakin bahwa tidak ada murid yang bodoh. Maka dari itu, sebaiknya harus ditanamkan di seluruh elemen-elemen sekolah dan wali murid, dikarenakan setiap manusia itu lahir dengan berbagai potensi yang

\footnotetext{
50 Takunas, "Pemikiran Pendidikan Islam Kh. Imam Zarkasyi," 158.
} 
berbeda-beda. ${ }^{51}$ Hal ini juga sangat didukung dengan teorinya Howard Gardner yakni teori Multiple Intelligences (kecerdasan majemuk) $)^{52}$ menurutnya, semua orang itu memiliki tingkat kecerdasan yang berbeda-beda dan memiliki cara penyelesaian yang berbeda-berbeda tergantung pada diri seseorang tersebut dalam menyelesaikan sebuah masalah tersebut selain itu dalam hal ini tingkat kecerdasannya masuk ke dalam Intrapersonal Intelegensi ${ }^{53}$ Senada dengan hal itu, Maslow juga selalu menekankan bahwasanya adanya kekuatan untuk menyelesaikan seseuatu hal yang ada pada diri seseorang di dalamnya mencakup motivasi yang tinggi dalam diri seseorang itu, maka dari hal itulah ia akan mudah dalam mengembangkan potensi yang dimilikinya secara utuh. Sebab, setiap orang melakukan sesuatu itu atas dasar apa yang diinginkannya, sehingga tercapainya sebuah tujuan yang dikehendakinya. ${ }^{54}$

Selain itu, KH. Imam Zarkasyi juga menegaskan bahwa meskipun adanya kesamaan antara sistem klasikal dan sistem asrama, akan tetapi beliau tidak akan menghapus berbagai elemen yang ada dan sangat penting dan harus ada serta sudah menjadi tradisi sistem pendidikan di sebuah pesantren. Sistem pendidikan tersebut adalah pengkajian kitab-kitab klasik atau biasa disebut dengan kitab kuning. Beliau mengarahkan kepada para santri agar dapat membaca dan memahami dengan betul kitab-kitab yang telah ada dan disediakan di pesantren salafiyah untuk dikajinya.

Selanjutnya, KH. Imam Zarkasyi memberikan beberapa metode dan kaidah pengajaran kepada guru-guru dalam proses belajar mengajar di kelas. Misalnya pembelajaran harus dimulai dari yang mudah dan sederhana, tidak tergesa-gesa berganti ke pelajaran yang lain sebelum santri dapat menafsirkan pembelajaran yang sudah dipelajari, prosedur belajar mengajar juga harus terstruktur dan sistematik, memperbanyak latihan apabila telah selesai pembelajaran dan lain-lain.

51 Takunas, 159.

52 Syarifah, "Konsep Kecerdasan Majemuk Howard Gardner," SUSTAINABLE: Jurnal Kajian Mutu Pendidikan 2, no. 2 (2019): 180, https://doi.org/10.32923/kjmp.v2i2.987.

${ }^{53}$ Syarifah, 182.

54 Ela Isnani Munawwaroh, "Humanistic Method Dalam Pembelajaran Bahasa Arab," Tarbawy: Jurnal Pendidikan Islam 5, no. 2 (2018): 110, https://doi.org/10.32923/tarbawy.v5i2.838. 
Metode dan kaidah tersebut bisa dipraktikkan oleh setiap guru dengan persyaratan bahwa guru terlebih dahulu harus memiliki dan menguasai metode dalam mengajar. Menurut pandangan KH. Imam Zarkasyi metode itu jauh lebih penting dibandingkan dengan materi, serta kepribadian seorang guru itu sangat penting dari pada metode tersebut. ${ }^{55}$ Dari penjelasan di atas, bahwa KH. Imam Zarkasyi telah mengemukakan dengan adanya sistem pendidikan yang sudah diterapkannya tersebut, efisiensi waktu pembelajaran dengan relatif waktu yang sedikit tetapi menghasilkan produk yang lebih besar dan bermutu serta metode pembelajaran yang baik berawal dari gabungan antara pemahaman yang baik terhadap pola pengajaran dan pemahaman terhadap kondisi anak didik.

Menurut Imam Zarkasyi terdapat sembilan metode pembelajaran di antaranya sebagai berikut. 1. Pembelajaran seharusnya dimulai dari yang mudah terlebih dahulu baru ke yang sederhana 2. Tidak tergesa-gesa untuk pindah ke pelajaran yang lain sebelum siswa dapat memahami betul pelajaran yang telah diberikan 3. Proses pengajaran harus dengan teratur dan sistematik 4. Memperbanyak latihan jika selesai pembelajaran 5. Guru tidak boleh bosan mengulangi pelajaran dengan soal-soal evaluasi 6. Guru hendaknya pandai-pandai dalam mengetahui dan mengukur kemampuan dan kondisi kepribadian siswa 7. Guru hendaknya pandai menarik perhatian siswa dengan latihan-latihan dan ulangan-ulangan yang bervariasi 8. Guru hendaknya selalu memotivasi siswa yang pandai dan tidak meremehkan siswa yang lemah 9. Guru hendaknya memperhatikan tingkat perbedaan kecerdasan dan kelemahan individu siswa. ${ }^{56}$

Terlepas dari penyataan di atas, Rudini menyatakan dalam jurnalnya bahwa perhatian terhadap akademik pendidikan khususnya keislaman yang ada di Indonesia ini bisa dibilang jauh dari kata kurang. Padahal, jika tradisi dari akademik di dalam pesantren menerapkan sistem pembelajaran yang tuntas maka pesantren

\footnotetext{
55 Takunas, "Pemikiran Pendidikan Islam Kh. Imam Zarkasyi," 157.

${ }^{56}$ Mumtazul Fikri, "Konsep Pendidikan Islam : Pendekatan Pendidikan Islam,” Jurnal Ilmiah
} 11, no. 1 (2011): 117-27. 
akan dapat mencetak generasi-generasi yang mempunyai wawasan yang sangat luas serta kepribadian yang sangat matang. Akan tetapi, dalam hal ini pemikiran Imam Zarkasyi sudah sangat bagus dalam melakukan pembaharuan. Salah satunya terkait metode pembelajaran yang diterapkannya. ${ }^{57}$

Oleh karena itu, untuk menjadi seorang pendidik di era generasi Alfa, yang mana generasi ini sangat akrab dengan teknologi akan informasi yang melimpah itu bukan hal yang mudah. Beberapa hal penting yang perlu disiapkan guru dalam lembaga pendidikan serta dalam menyiapkan sistem pendidikan untuk generasi ini dapat dilakukan dengan mengasah kemampuan intrapersonal intelegensi yang dimiliki peserta didik dengan cara menerapkan 9 metode pembelajaran dan sistem pendidikan yang sudah dijelaskan dalam pemikiran KH. Imam Zarkasyi di atas.

Disamping itu, dengan menerapkan beberapa hal yang sudah dikemukakan di atas ini sangat membantu seorang guru dalam membentuk serta mengetahui intrapersonal intelligences pada diri seseorang terutama potensi-potensi yang dimiliki setiap peserta didiknya. Menurut Gardner, kecerdasan yang dimiliki anak itu tidak hanya sebatas diartikan sebagai IQ saja seperti pemahaman kebanyakan orang saat ini, namun pada dasarnya kecerdasan juga menyangkut tentang kemampuan seseorang dalam memecahkan dan menyelesaikan masalah serta kemampuan dalam menghasilkan produk atau gagasan. ${ }^{58}$

Gardner menyatakan bahwasanya dengan adanya intelegensi intrapersonal setiap orang mempunyai kemampuan dalam menganalisis dirinya sendiri. Mereka dapat mengetahui dengan sangat baik tentang dirinya sendiri. Selain itu. dia dapat mengetahui apa yang diinginkannya, apa yang akan dilaksanakan dan terbaik bagi dirinya sendiri, dapat membagikan tanggapan pada keadaan tertentu, dan dapat menyikapi dengan baik, serta dapat intropeksi diri. ${ }^{59}$ Oleh karena itu, dengan adanya

57 Rudini, “Aktualisasi Nilai-Nilai Islam Dalam Pembentukan Karakter Mahasiswa Di Pondok Pesantren Nurul Ummah Kotagede Yogyakarta," Tarbawy : Jurnal Pendidikan Islam 7, no. 1 (2020): 48, https://doi.org/10.32923/tarbawy.v7i1.1185.

${ }^{58}$ Syarifah, "Konsep Kecerdasan Majemuk Howard Gardner," 183.

${ }^{59}$ Fitri Oviyanti, "Urgensi Kecerdasan Interpersonal Bagi Guru," Tadrib: Jurnal Pendidikan Agama Islam 3, no. 1 (2017): 75, https://doi.org/10.19109/tadrib.v3i1.1384. 
kecerdasan ini sangat membantu peserta didik khususnya pendidik dalam mengembangkan potensi yang ada di dalam diri dan membantu mengekspresikan diri menjadi lebih baik lagi, serta mampu berkarya dengan sangat optimal. Dalam hal ini dapat disimpulkan bahwa pemikiran dari KH. Imam Zarkasyi untuk menjawab tantangan dunia pendidikan di era generasi alpha atau generasi milenial ini sangat relevan dengan salah satu kecerdasan pada teori Gardner yakni intelegensi intrapersonal.

\section{Kesimpulan}

Berdasarkan paparan di atas menunjukkan bahwa pemikiran-pemikiran $\mathrm{KH}$ Imam Zarkasi tentang Pendidikan masih sangat relevan untuk diaplikasikan pada masa kini dalam upaya membentuk intrapersonal intelegensi. Di antara pemikirannya tersebut adalah, pertama, bahwa upaya pembentukan intrapersonal intelegensi bisa terjadi melalui dua cara; yaitu secara sengaja, yaitu dibentuk melalui lembaga-lembaga pendidikan seperti sekolah dan pondok pesantren, dan secara tidak sengaja yaitu melalui adanya interaksi dengan masyarakat dan alam sekitar. Kedua, cara belajar terbaik dalam membentuk Kecerdasan intrapersonal adalah melalui latihan secara individu antara lain; dengan mempercayakan kepada anak untuk melakukan tugasnya sendiri dengan penuh tanggung jawab, diberi kesempatan untuk mengambil keputusan sendiri dan bertanggung jawab atas terhadap keputusannya, dan kegiatan serupa lainnya. Pemikiran-pemikiran seperti ini telah diaplikasikan KH Imam Zarkasi melalui Lembaga yang dikembangkannya yaitu di Pondok Pesantren Gontor. Dalam upaya pembaharuannya beliau di antaranya adalah penerapan pembelajaran dengan sistem klasikal, penggunaan metode pembelajaran yang memberikan peluang kepada anak guna mengembangkan daya fikirnya dengan kritis independen dan bertanggung jawab, dan menyediakan kegiatan ekstrakulikuler sebagai wadah untuk peserta didik mengembangkan dirinya 


\section{Daftar Pustaka}

Assiroji, Dwi Budiman. "Konsep Pendidikan Islam Menurut KH. Imam Zarkasyi." Jurnal Bina Ummat 1, no. 1 (2018): 33-46.

Aufin, Mohammad. "Kontribusi K.H Imam Zarkasyi Dalam Pemikiran Pendidikan Islam (Pesantren)." Journal of Chemical Information and Modeling 53, no. 9 (2019): 131-47.

Fatihah, Imroatul. "Kepemimpinan KH. Imam Zarkasyi Di Pondok Modern Darussalam Gontor." JIEM (Journal of Islamic Education Management) 2, no. 2 (2018): 26. https://doi.org/10.24235/jiem.v2i2.3407.

Fikri, Mumtazul. "Konsep Pendidikan Islam: Pendekatan Pendidikan Islam." Jurnal Ilmiah 11, no. 1 (2011): 117-27.

Habibah. "Penerapan Strategi Multiple Intelligences Pada Mata Pelajaran Pendidikan Agama Islam (Studi Kasus Di SMP Negeri 3 Sungailiat)." Edugama: Jurnal Kependidikan Dan Sosial Keagamaan 5, no. 1 (2019): 6085. https://doi.org/10.32923/edugama.v5i1.959.

Hanisah. "Meningkatkan Kecerdasan Intrapersonal Anak Melalui Kegiatan Berceritera Berbantuan Media Film/VCD Di Kelompok B5 RA Ummatan Wahidah Di Kota Curup." Universitas Bengkulu, 2014.

Ina. "Kecerdasan Intrapersonal." Dosen Psikologi.com, 2019.

Jayanti, Mustika Arif, and Achmad Maulana Malik Jamil. "Hubungan Multiple Intelligences Pada Unsur Intrapersonal Dengan IPK Mahasiswa Pendidikan Geografi Universitas Kanjuruhan Malang." Jurnal Pendidikan Geografi 24, no. 2 (2019): 119-31. https://doi.org/10.17977/um017v24i22019p119.

Kasih, Ayunda Pinanti. "9 Jenis Kecerdasan Anak Dan Cara Mengembangkannya." Kompas.com, 2020.

Misbah. K.H. Imam Zarkasyi Dari Gontor: K.H. Imam Zarkasyi Dari Gontor. Kediri: Gontor Press 2009, 2009.

Mu'minah, Najwa. "Character Buliding Dalam Konsep Pendidikan Imam Zarkasyi Ditinjau Dari Filsafat Moral Ibnu Miskawaih.” Jurnal Filsafat 25, no. 1 (2015): 100-133.

Muafiah, Evi. "Strategi Pembelajaran Multiple Intelligences Di TK/RA Ponorogo." ThufuLA: Jurnal Inovasi Pendidikan Guru Raudhatul Athfal 4, no. 1 (2017): 63. https://doi.org/10.21043/thufula.v4i1.1977.

Mumtani'ah. "Pembaharuan Sistem Pendidikan Di Pesantren (Studi Kasus Di Pondok Pesantren An-Nur Rejosari, Pakis, Magelang)." Al-Insyiroh: Jurnal Studi KeislamaEDUGAMA: Jurnal Kependidikan Dan Sosial Keagamaan 5, no. 1 (2019): 155-93. https://doi.org/10.35309/alinsyiroh.v6i1.3819.

Munawwaroh, Ela Isnani. "Humanistic Method Dalam Pembelajaran Bahasa Arab." Tarbawy: Jurnal Pendidikan Islam 5, no. 2 (2018): 109-15. https://doi.org/10.32923/tarbawy.v5i2.838.

Nurdianto, Saifuddin Alif. "K. H. Imam Zarkasyi: Membangun Karakter Umat Dengan Modernisasi Pesantren (1926-1936),” 2019, 181-90. 
https://doi.org/10.31227/osf.io/q738y.

Nurhakim, Moh. "Imam Zarkasyi Dan Pembaharuan Pesantren: Rekonstruksi Aspek Kurikulum, Menejemen Dan Etika Pendidikan." Progresiva : Jurnal

Pemikiran Dan Pendidikan Islam 7, no. 1 (2018): 1. https://doi.org/10.22219/progresiva.v7i1.7404.

Oviyanti, Fitri. "Urgensi Kecerdasan Interpersonal Bagi Guru." Tadrib: Jurnal Pendidikan Agama Islam 3, no. 1 (2017): 75. https://doi.org/10.19109/tadrib.v3i1.1384.

Purnomo, Hadi. Pendidikan Islam Integrasi Nilai-Nilai Humanis, Liberasi Dan Transendensi; Sebuah Gagasan Paradigma Baru Pendidikan. Edited by Asnawan. Cetakan Ed. Yogyakarta: Absolute Media, 2016.

Rahmatan, Perspektif, and L I L Alamin. "Rahmatan Lil Alamin Journal of Peace Education and Islamic Study" 1, no. 1 (2018): 1-14.

Rofiq, Ahmad Choirul. "Perspektif K.H. Imam Zarkasyi Mengenai Kesatuan Ilmu Pengetahuan.” Ta'allum: Jurnal Pendidikan Islam 6, no. 2 (2018): 313-46. https://doi.org/10.21274/taalum.2018.6.2.313-346.

Rudini. "Aktualisasi Nilai-Nilai Islam Dalam Pembentukan Karakter Mahasiswa Di Pondok Pesantren Nurul Ummah Kotagede Yogyakarta." Tarbawy: Jurnal Pendidikan Islam 7, no. 1 (2020): 47-60. https://doi.org/10.32923/tarbawy.v7i1.1185.

Salik, Mohamad, and Ali Mas'ud. "Pesantren Dan Upaya Menangkal Tumbuhnya Radikalisme: Analisis Gagasan KH. Marzuki Mustamar." Jurnal Pendidikan Agama Islam (Journal of Islamic Education Studies) 8, no. 1 (2020): 1-20. https://doi.org/10.15642/jpai.2020.8.1.1-20.

Subri. "Manusia Dan Pendidikan Islam." Jurnal Tarbawi Jurnal Pendidikan Islam 4, no. 2 (2017): 242-51.

Sulaiman, Rusydi. "Hakikat Pendidikan Pesantren: Studi Atas Falsafah, Idealisme, Dan Manajemen Pendidikan Pondok Pesantren Al Islam Kemuja Mendobarat Bangka." EDUGAMA: Jurnal Kependidikan Dan Sosial Keagamaan 5, no. 2 (2019): 2614-0217.

Syarifah. "Konsep Kecerdasan Majemuk Howard Gardner." SUSTAINABLE: Jurnal Kajian Mutu Pendidikan 2, no. 2 (2019): 176-97. https://doi.org/10.32923/kjmp.v2i2.987.

Takunas, Rusli. "Pemikiran Pendidikan Islam Kh. Imam Zarkasyi." Scolae: Journal of Pedagogy 1, no. 2 (2018): 154-60.

Umar Bukhory. "KH. Imam Zarkasyi Dan Genre Baru Pondok Pesantren (Refleksi Seorang Cucu Murid).” Journal of Islamic Studies 1, no. 2 (2016): 259-72.

Utami, S.W. "Multiple Intelligences: Platform Global Paling Efektif Untuk Pendidikan Abad Ke-21 Dalam Pendidikan Dan Pembelajaran." Prosiding Seminar Nasional \& Call Paper Psikologi Pendidikan 2019, no. April (2019): 251-57.

Widyaningsih, Tatik. "Revolusi Industri 4.0 Dan Pendidikan Anak Usia Dini 
| ROBIATUL, RYAN, M. SALIK | Relevansi Pemikiran Pendidikan...

Untuk Generasi Alfa: Sebuah Telaah." Prosiding Seminar Nasional Pendidikan FKIP 2, no. 1 (2019): 318-19.

Zed, Mestika. "Metode Penelitian Kepustakaan," Cetakan Ke., 1-94. Jakarta: Yayasan Pustaka Obor Indonesia, 2014. 